\title{
Natronorubrum sediminis sp. nov., an archaeon isolated from a saline lake
}

Correspondence

A. Ventosa

ventosa@us.es

\author{
M. C. Gutiérrez, ${ }^{1}$ A. M. Castillo, ${ }^{1}$ P. Corral, ${ }^{1}$ H. Minegishi ${ }^{2}$ and A. Ventosa ${ }^{1}$ \\ 1'Department of Microbiology and Parasitology, Faculty of Pharmacy, University of Sevilla, 41012 \\ Sevilla, Spain \\ ${ }^{2}$ Bio-Nano Electronics Research Center, Toyo University, 2100 Kujirai, Kawagoe, Saitama 350- \\ 8585, Japan
}

\begin{abstract}
Two novel haloalkaliphilic archaea, strains CG- $6^{\top}$ and CG-4, were isolated from sediment of the hypersaline Lake Chagannor in Inner Mongolia, China. Cells of the two strains were pleomorphic, non-motile and strictly aerobic. They required at least $2.5 \mathrm{M} \mathrm{NaCl}$ for growth, with optimum growth at $3.4 \mathrm{M} \mathrm{NaCl}$. They grew at $\mathrm{pH} 8.0-11.0$, with optimum growth at $\mathrm{pH} 9.0$. Hypotonic treatment with less than $1.5 \mathrm{M} \mathrm{NaCl}$ caused cell lysis. The two strains had similar polar lipid compositions, possessing $\mathrm{C}_{20} \mathrm{C}_{20}$ and $\mathrm{C}_{20} \mathrm{C}_{25}$ derivatives of phosphatidylglycerol and phosphatidylglycerol phosphate methyl ester. No glycolipids were detected. Comparison of $16 \mathrm{~S}$ rRNA gene sequences and morphological features placed them in the genus Natronorubrum. 16S rRNA gene sequence similarities to strains of recognized species of the genus Natronorubrum were 96.2-93.8\%. Detailed phenotypic characterization and DNA-DNA hybridization studies revealed that the two strains belong to a novel species in the genus Natronorubrum, for which the name Natronorubrum sediminis sp. nov. is proposed; the type strain is CG- $6^{\top}$ (=CECT $7487^{\top}$ $=$ CGMCC $1.8981^{\top}=$ JCM $15982^{\top}$ ).
\end{abstract}

Extremely halophilic archaea have been isolated from various hypersaline environments such as hypersaline lakes, solar salterns, saline soils and salt mines. They are classified within the family Halobacteriaceae (Grant et al., 2001; Ventosa, 2006) and members of this family are ubiquitous in these hypersaline environments. They are usually pink- to red-pigmented due to the presence of carotenoids (Kamekura \& Dyall-Smith, 1995; Hezayen et al., 2001; Grant et al., 2001). At the time of writing, the aerobic, extremely halophilic archaea were classified in 27 genera (Grant et al., 2001; Ventosa, 2006; Castillo et al., 2006a, b; Savage et al., 2007, 2008; Burns et al., 2007; Gutiérrez et al., 2007; Bardavid et al., 2007).

In 1999, Xu et al. (1999) described the genus Natronorubrum to accommodate two novel haloalkaliphilic species, Natronorubrum bangense and Natronorubrum tibetense, which were isolated from sediment of Bange salt-alkaline lake in Tibet, China. On the basis of 16S rRNA gene sequence analysis, phenotypic properties and polar lipid composition, two more species, Natronorubrum aibiense (Cui et al., 2006) and Natronorubrum sulfidifaciens

The GenBank/EMBL/DDBJ accession numbers for the $16 \mathrm{~S}$ rRNA gene sequences of strains CG- $6^{\top}$ and CG-4 are FN376859 and FN376860, respectively.

A thin-layer chromatogram of polar lipids extracted from strains CG- $6^{\top}$ and CG-4 and related strains is available as supplementary material with the online version of this paper.
(Cui et al., 2007), were included in the genus. Recently, Oren et al. (2009) emended the descriptions of nine genera of the family Halobacteriaceae, including the genus Natronorubrum. The main features of the species of Natronorubrum are as follows: cells are pleomorphic, flat, triangular, square or disc-shaped and stain Gram-negative; cells lyse in distilled water; they are extremely halophilic, with growth occurring in media containing 2.1-5.2 M $\mathrm{NaCl}$; they are neutrophilic or alkaliphilic with growth up to $\mathrm{pH} \mathrm{11;} \mathrm{they} \mathrm{metabolize} \mathrm{sugars,} \mathrm{in} \mathrm{some} \mathrm{cases} \mathrm{with}$ formation of acids; the major polar lipids are $\mathrm{C}_{20} \mathrm{C}_{20}$ and $\mathrm{C}_{20} \mathrm{C}_{25}$ glycerol diether derivatives of phosphatidylglycerol and phosphatidylglycerol phosphate methyl ester; and they have DNA G + C contents of 59.9-61.2 mol\%.

In this study, the taxonomic features of two strains, CG- $6^{\mathrm{T}}$ and CG-4, isolated from sediment of the hypersaline Lake Chagannor, located in Inner Mongolia Autonomous Region, China, were investigated. On the basis of the data presented in this work, strains CG- $6^{\mathrm{T}}$ and CG-4 represent a novel species of the genus Natronorubrum.

The two haloalkaliphilic strains (CG-6 ${ }^{\mathrm{T}}$ and CG-4) were isolated from a sediment sample from Lake Chagannor $\left(43^{\circ} 21.583^{\prime} \mathrm{N} 113^{\circ} 08.193^{\prime} \mathrm{E}\right)$. At the time of sampling, the water of the lake had a temperature of $17.1^{\circ} \mathrm{C}$, the $\mathrm{pH}$ was 9.5 , the conductivity was $21.3 \mathrm{mS} \mathrm{cm} \mathrm{cm}^{-1}$ and the salinity was $16 \%$. Approximately $0.5 \mathrm{~g}$ sediment sample was resuspended in alkaline saline medium and incubated 
aerobically at $37^{\circ} \mathrm{C}$; strains CG- $6^{\mathrm{T}}$ and CG-4 were isolated after 7 days of incubation and plated on alkaline saline solid medium until pure. The alkaline isolation medium contained the following $\left(\mathrm{g} \mathrm{l}^{-1}\right)$ : peptone (Difco), 5.0; meat extract (Difco), 3.0; $\mathrm{KH}_{2} \mathrm{PO}_{4}, 3.9 ; \mathrm{MgSO}_{4} .7 \mathrm{H}_{2} \mathrm{O}, 0.78$; $\mathrm{NaCl}, 157.0 ; \mathrm{Na}_{2} \mathrm{CO}_{3}, 21.4$; and $\mathrm{NaHCO}_{3}, 17.0 . \mathrm{NaCl}$, $\mathrm{Na}_{2} \mathrm{CO}_{3}$ and $\mathrm{NaHCO}_{3}$ were autoclaved separately and added to the medium prior to incubation (Duckworth et al., 1996). Solid medium contained $2.0 \%(\mathrm{w} / \mathrm{v})$ agar; strains were maintained on this solid medium.

Phenotypic characterization was carried out in accordance with the recommended minimal standards for the description of new taxa in the order Halobacteriales (Oren et al., 1997). For the determination of cellular morphology and motility, a sample from an exponentially grown liquid culture was examined by phase-contrast light microscopy. The morphology of the colonies, their pigmentation and their size were observed on the isolation and maintenance solid medium (with different salt concentrations) after 10 days of incubation. Growth at different concentrations of salts was determined on isolation medium supplemented with $0,0.5,1,3,5,7$, $10,15,20,25$ or $30 \%(\mathrm{w} / \mathrm{v})$ total salts. The $\mathrm{pH}$ range for growth was determined on the medium at $\mathrm{pH}$ 5.0-11.0 (at $0.5 \mathrm{pH}$ unit intervals), achieved using appropriate biological buffers $\left(\mathrm{Na}_{2} \mathrm{HPO}_{4} / \mathrm{Na}_{2} \mathrm{HPO}_{4}\right.$ for $\mathrm{pH}$ below 8.0, $\mathrm{Na}_{2} \mathrm{CO}_{3} / \mathrm{NaHCO}_{3}$ for $\mathrm{pH} 8.0-10.0$ and $\mathrm{Na}_{2} \mathrm{HPO}_{4} / \mathrm{NaOH}$ for $\mathrm{pH}$ higher than 10.0), as described previously (Gomori, 1955). The $\mathrm{pH}$ was readjusted after sterilization and growth was assessed using optical density at $600 \mathrm{~nm}$. The temperature range for growth was determined at 15$55{ }^{\circ} \mathrm{C}$ (at intervals of $5.0{ }^{\circ} \mathrm{C}$ ). Catalase activity was assayed by adding $3 \% \mathrm{H}_{2} \mathrm{O}_{2}$ to culture plates. The oxidase reaction was performed on filter paper moistened with a $1 \%(\mathrm{w} / \mathrm{v})$ aqueous solution of $N, N, N^{\prime}, N^{\prime}$-tetramethyl- $p$-phenylenediamine (Barrow \& Feltham, 1993). Anaerobic growth was tested in the presence of $5 \%$ nitrate and $3 \% \mathrm{~L}$-arginine in filled stoppered tubes (Oren et al., 1997). To determine the utilization of different organic substrates as carbon and energy or as carbon, nitrogen and energy sources, a medium containing yeast extract at $0.05 \%(\mathrm{w} / \mathrm{v})$ supplemented with $1 \%(\mathrm{w} / \mathrm{v})$ of the tested substrate was used (Torreblanca et al., 1986). Susceptibility to antibiotics was determined on agar medium plates by using antibiotic discs containing ampicillin $(10 \mu \mathrm{g})$, bacitracin (10 $\mathrm{U})$, chloramphenicol $(30 \mu \mathrm{g})$, erythromycin $(15 \mu \mathrm{g})$, gentamicin $(10 \mu \mathrm{g})$, nalidixic acid $(30 \mu \mathrm{g})$, neomycin $(10 \mu \mathrm{g})$, novobiocin $(30 \mu \mathrm{g})$, penicillin $\mathrm{G}(10 \mathrm{U})$, rifampicin $(30 \mu \mathrm{g})$, streptomycin $(10 \mu \mathrm{g})$ and tetracycline $(30 \mu \mathrm{g})$. Strains CG- $6^{\mathrm{T}}$ and CG-4 were oxidase- and catalasepositive. Other phenotypic characteristics are summarized in Table 1 and the species description. The results of the utilization of different substrates and antibiotic susceptibility are included in the species description.

Polar lipids of strain CG- $6^{\mathrm{T}}$ and CG- 4 were extracted with chloroform/methanol as described previously (Kamekura, 1993). TLC was carried out using Merck HPTLC silica gel
Table 1. Differentiation of Natronorubrum sediminis sp. nov. from other species of the genus

Strains: 1, Nrr. sediminis sp. nov. strains CG-6 ${ }^{\mathrm{T}}$ and CG-4; 2, Nrr. sulfidifaciens JCM $14089^{\mathrm{T}}$ (data from Cui et al., 2007 and this study); 3, Nrr. tibetense AS $1.2123^{\mathrm{T}}$ (Xu et al., 1999 and this study); 4, Nrr. bangense AS $1.1984^{\mathrm{T}}$ (Xu et al., 1999); 5, Nrr. aibiense JCM $13488^{\mathrm{T}}$ (Cui et al., 2006).

\begin{tabular}{|lccccc|}
\hline Characteristic & $\mathbf{1}$ & $\mathbf{2}$ & $\mathbf{3}$ & $\mathbf{4}$ & $\mathbf{5}$ \\
\hline Cell shape & PL & PL & PL & PL & R \\
Motility & - & + & - & - & + \\
Optimum NaCl concentration & 20 & 18 & 20 & 22.5 & 18 \\
$\quad$ \%, w/v) & & & & & \\
$\mathrm{H}_{2}$ S formation & - & + & - & - & - \\
Nitrate reduction & + & + & - & - & + \\
Indole production & - & + & + & + & + \\
Tween 80 hydrolysis & + & - & - & - & - \\
Gelatin hydrolysis & - & - & + & - & - \\
Utilization of: & & & & & \\
$\quad$ D-Glucose & + & - & $+\dagger$ & + & + \\
$\quad$ D-Galactose & - & - & - & - & + \\
D-Fructose & + & - & + & + & + \\
D-Xylose & + & + & - & - & - \\
DNA G+C content $($ mol\%) & $61.9-62.5$ & 60.9 & 60.1 & 59.9 & 61.2 \\
& & & & & \\
\hline
\end{tabular}

${ }^{\star}$ PL, Pleomorphic; R, rod.

$\dagger$ Weak growth in our study.

60 plates in the solvent system chloroform/methanol/acetic acid/water $(85: 22.5: 10: 4$, by vol.). Glycolipids were determined as purple spots by spraying with $0.5 \% \alpha$ naphthol in methanol/water $(1: 1)$ and then with sulfuric acid/ethanol $(1: 1)$, followed by heating at $160{ }^{\circ} \mathrm{C}$. The polar lipids of strains CG- $6^{\mathrm{T}}$ and CG-4 were $\mathrm{C}_{20} \mathrm{C}_{20}$ and $\mathrm{C}_{20} \mathrm{C}_{25}$ derivatives of phosphatidylglycerol and phosphatidylglycerol phosphate methyl ester, which are the major phospholipids found in members of the genus Natronorubrum (Oren et al., 2009). No glycolipids were detected (Supplementary Fig. S1, available in IJSEM Online).

Chromosomal DNA from strains CG-6 ${ }^{\mathrm{T}}$ and CG-4 was isolated and purified according to the method described by Marmur (1961). Genomic DNA G+C contents were determined from the mid-point value $\left(T_{\mathrm{m}}\right)$ of each of the thermal denaturation profiles (Marmur \& Doty, 1962) by using the equation of Owen \& Hill (1979). The genomic DNA G $+C$ contents of strains CG- $6^{\mathrm{T}}$ and CG-4 were 62.5 and $61.9 \mathrm{~mol} \%$, respectively. These values are quite close to those of species of the genus Natronorubrum (59.961.2 mol\%; Table 1). The 16S rRNA genes of strains CG$6^{\mathrm{T}}$ and CG-4 were amplified by PCR using three universal primer sets as described previously (López-García et al., 2001; Arahal et al., 1996). Almost-complete $16 \mathrm{~S}$ rRNA gene sequences of strains CG-6 ${ }^{\mathrm{T}}$ (1371 bp) and CG-4 (1371 bp) were determined. The ARB software package (Ludwig et al., 2004) was used for 16S rRNA gene sequence analysis. 
Following the recommendations of Ludwig et al. (1998), alternative treeing methods (maximum-parsimony, neighbour-joining and maximum-likelihood) were used (Saitou \& Nei, 1987). Identification of phylogenetic neighbours and calculation of pairwise 16S rRNA gene sequence similarities were achieved using the EzTaxon server (http:// www.eztaxon.org/; Chun et al., 2007). 16S rRNA gene sequence data showed that strains CG- $6^{\mathrm{T}}$ and CG-4 shared a high degree of similarity (99.8\%); they were closely related to Nrr. sulfidifaciens JCM $14089^{\mathrm{T}}$ (similarities of 96.2 and $96.1 \%$, respectively), Nrr. tibetense AS $1.2123^{\mathrm{T}}$ (95.5 and $95.4 \%)$, Nrr. bangense AS $1.1984^{\mathrm{T}}$ (95.1 and 95.1) and Nrr. aibiense JCM $13488^{\mathrm{T}}$ (93.9 and $93.8 \%$ ). Lower similarities were obtained with the type strains of species of the genera Haloterrigena and Natrinema. The maximum-parsimony phylogenetic tree (Fig. 1) showed that both strains were within the cluster made up of the type strains of Natronorubrum species. Trees constructed according to the neighbour-joining and maximum-likelihood methods resulted in highly similar tree topologies, so only the maximum-parsimony results are shown.

DNA-DNA hybridization experiments were carried out to determine the genotypic relatedness between the two isolates. These studies were carried out by following the competition procedure of Johnson (1994). Competitor DNAs were sonicated (Braum Melsungen) at $50 \mathrm{~W}$ for two periods of $15 \mathrm{~s}$. Membrane filters $0.5 \mathrm{~cm}$ in diameter (HAHY; Millipore) and containing reference DNA (25 $\mu \mathrm{g}$ $\mathrm{cm}^{-2}$ ) were placed in $5 \mathrm{ml}$ screw-capped vials (Greiner) containing labelled, sheared, denatured DNA and denatured, sheared competitor DNA. The ratio of the concentration of the competitor DNA to that of the labelled DNA was at least 150:1. The final volume was $140 \mu \mathrm{l}$ and the solvent in which the determinations were carried out was a mixture of $2 \times$ SSC and $30 \%$ formamide. The optimal hybridization temperatures were 57.2 and $57.0{ }^{\circ} \mathrm{C}$, which are within the limits of validity for the filter method (De Ley \& Tijtgat, 1970). The vials were shaken gently for $18 \mathrm{~h}$ in a water bath (Grant Instruments); these procedures were done in triplicate. After hybridization, the filters were washed in $2 \times$ SSC at the optimal renaturation temperatures given above. The radioactivity bound to the filters was measured in a liquid scintillation counter
(Beckman Instruments) and relatedness was calculated according to Johnson (1994). At least two independent determinations were carried out for each experiment and the reported results are mean values. DNA-DNA hybridization values between strains CG- $6^{\mathrm{T}}$ and CG- 4 were 100 and $98 \%$ (the latter being for the reverse hybridization). These data clearly support the conclusion that the two strains are members of the same species (Stackebrandt et al., 2002).

On the basis of phenotypic characteristics (Table 1), polar lipid profiles, DNA $\mathrm{G}+\mathrm{C}$ contents and $16 \mathrm{~S}$ rRNA gene sequence analyses, strains CG- $6^{\mathrm{T}}$ and CG- 4 are considered to represent a novel species of the genus Natronorubrum, for which the name Natronorubrum sediminis sp. nov. is proposed.

\section{Description of Natronorubrum sediminis sp. nov.}

Natronorubrum sediminis (se.di'mi.nis. L. n. sedimen, -inis sediment; L. gen. n. sediminis of a sediment).

Cells are Gram-negative, non-motile, pleomorphic rods, $4.0-6.0 \times 0.8-1.0 \mu \mathrm{m}$. Colonies are circular, smooth, entire, of shining aspect, pink-pigmented and $1.0-4.0 \mathrm{~mm}$ in diameter after 10 days incubation at $37{ }^{\circ} \mathrm{C}$ on plates containing $20 \%(\mathrm{w} / \mathrm{v})$ total salts. Extremely halophilic; the cells lyse in water. Growth occurs in $2.5-5.0 \mathrm{M} \mathrm{NaCl}$ and is optimal in $3.4 \mathrm{M} \mathrm{NaCl}$. $\mathrm{MgCl}_{2}$ is not required for growth. The $\mathrm{pH}$ and temperature ranges for growth are $\mathrm{pH} 8.0$ 11.0 (optimum at $\mathrm{pH} 9.0$ ) and $25-50{ }^{\circ} \mathrm{C}$ (optimum at $37^{\circ} \mathrm{C}$ ). Chemo-organotrophic, aerobic, and oxidase- and catalase-positive. Indole is not produced from tryptophan. Methyl red, Voges-Proskauer and Simmons' citrate tests are negative. Does not grow anaerobically in the presence of nitrate or L-arginine. Starch, gelatin, DNA, aesculin and casein are not hydrolysed. Urea and Tween 80 are hydrolysed. Produces arginine dihydrolase and lysine decarboxylase, but not ornithine decarboxylase. Nitrate is reduced to nitrite; gas is not produced from nitrite. $\mathrm{H}_{2} \mathrm{~S}$ is not produced from $\mathrm{Na}_{2} \mathrm{~S}_{2} \mathrm{O}_{3}$. Utilizes D-glucose, D-fructose, D-xylose, D-arabinose, D-mannose and L-asparagine. No growth is observed on glycerol, maltose, trehalose, starch, propionate, fumarate, acetate, L-lysine, D-mannitol, Dsorbitol, lactose, D-galactose, raffinose, D-ribose, malate,

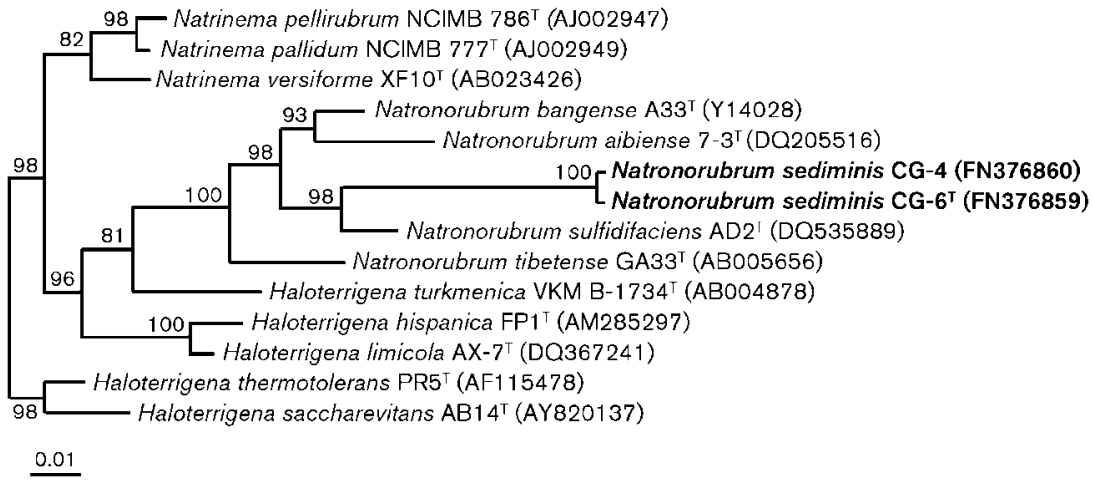

Fig. 1. Maximum-parsimony phylogenetic tree based on 16S rRNA gene sequence comparisons showing the relationships between Natronorubrum sediminis sp. nov. strains CG- $6^{\top}$ and CG-4 and strains of species of the genus Natronorubrum and other related haloarchaea. Bootstrap values $>80 \%$ (based on 1000 replications) are shown. GenBank/ EMBL accession numbers are given in parentheses. Bar, $0.01 \%$ sequence divergence. 
succinate, glutamate, isoleucine, L-serine or glycine. Sensitive to novobiocin $(30 \mu \mathrm{g})$. Resistant to ampicillin $(10 \mu \mathrm{g})$, bacitracin $(10 \mathrm{U})$, chloramphenicol $(30 \mu \mathrm{g})$, erythromycin $(15 \mu \mathrm{g})$, gentamicin $(10 \mu \mathrm{g})$, nalidixic acid $(30 \mu \mathrm{g})$, neomycin $(10 \mu \mathrm{g})$, penicillin $\mathrm{G}(10 \mathrm{U})$, rifampicin $(30 \mu \mathrm{g})$, streptomycin $(10 \mu \mathrm{g})$ and tetracycline $(30 \mu \mathrm{g})$. The polar lipids are $\mathrm{C}_{20} \mathrm{C}_{20}$ and $\mathrm{C}_{20} \mathrm{C}_{25}$ derivatives of phosphatidylglycerol and phosphatidylglycerol phosphate methyl ester. No glycolipids are detected. The DNA G +C content is $61.9-62.5 \mathrm{~mol} \%\left(T_{\mathrm{m}}\right)$.

The type strain is CG- $6^{\mathrm{T}}\left(=\mathrm{CECT} 7487^{\mathrm{T}}=\mathrm{CGMCC}\right.$ $1.8981^{\mathrm{T}}=\mathrm{JCM} 15982^{\mathrm{T}}$ ), isolated from sediment of the saline Lake Chagannor in Inner Mongolia, China. The DNA G $+\mathrm{C}$ content of the type strain is $62.5 \mathrm{~mol} \%$.

\section{Acknowledgements}

We are grateful to M. Kamekura for help with the polar lipid analysis and critical reading of the manuscript and to J. Euzéby for his help and valuable suggestions regarding the etymology. This study was supported by grants from the Spanish Ministerio de Educacion y Ciencia (BIO2006-06927), the National Science Foundation (NSF, award 0919290) and the Junta de Andalucía (P06-CVI-01829). FEDER funds co-financed this project.

\section{References}

Arahal, D. R., Dewhirst, F. E., Paster, B. J., Volcani, B. E. \& Ventosa, A. (1996). Phylogenetic analyses of some extremely halophilic archaea isolated from Dead Sea water, determined on the basis of their $16 \mathrm{~S}$ rRNA sequences. Appl Environ Microbiol 62, 3779-3786.

Bardavid, R. E., Mana, L. \& Oren, A. (2007). Haloplanus natans gen. nov., sp. nov., an extremely halophilic gas-vacuolate archaeon isolated from Dead Sea-Red Sea water mixtures in experimental outdoor ponds. Int J Syst Evol Microbiol 57, 780-783.

Barrow, G. I. \& Feltham, R. K. A. (1993). Cowan and Steel's Manual for the Identification of Medical Bacteria, 3rd edn. Cambridge: Cambridge University Press.

Burns, D. G., Janssen, P. H., Itoh, T., Kamekura, M., Li, Z., Jensen, G., Rodríguez-Valera, F., Bolhuis, H. \& Dyall-Smith, M. L. (2007). Haloquadratum walsbyi gen. nov., sp. nov., the square haloarchaeon of Walsby, isolated from saltern crystallizers in Australia and Spain. Int J Syst Evol Microbiol 57, 387-392.

Castillo, A. M., Gutiérrez, M. C., Kamekura, M., Ma, Y., Cowan, D. A., Jones, B. E., Grant, W. D. \& Ventosa, A. (2006a). Halovivax asiaticus gen. nov., sp. nov., a novel extremely halophilic archaeon isolated from Inner Mongolia, China. Int J Syst Evol Microbiol 56, 765-770.

Castillo, A. M., Gutiérrez, M. C., Kamekura, M., Xue, Y., Ma, Y., Cowan, D. A., Jones, B. E., Grant, W. D. \& Ventosa, A. (2006b). Halostagnicola larsenii gen. nov., sp. nov., an extremely halophilic archaeon from a saline lake in Inner Mongolia, China. Int J Syst Evol Microbiol 56, 1519-1524.

Chun, J., Lee, J.-H., Jung, Y., Kim, M., Kim, S., Kim, B. K. \& Lim, Y. W. (2007). EzTaxon: a web-based tool for the identification of prokaryotes based on $16 \mathrm{~S}$ ribosomal RNA gene sequences. Int J Syst Evol Microbiol 57, 2259-2261.

Cui, H.-L., Tohty, D., Feng, J., Zhou, P.-J. \& Liu, S.-J. (2006). Natronorubrum aibiense sp. nov., an extremely halophilic archaeon isolated from Aibi salt lake in Xin-Jiang, China, and emended description of the genus Natronobacterium. Int J Syst Evol Microbiol 56, 1515-1517.
Cui, H.-L., Tohty, D., Liu, H.-C., Liu, S.-J., Oren, A. \& Zhou, P.-J. (2007). Natronorubrum sulfidifaciens sp. nov., an extremely haloalkaliphilic archaeon isolated from Aiding salt lake in Xin-Jiang, China. Int J Syst Evol Microbiol 57, 738-740.

De Ley, J. \& Tijtgat, R. (1970). Evaluation of membrane filter methods for DNA-DNA hybridization. Antonie van Leeuwenhoek 36, 461-474.

Duckworth, A. W., Grant, W. D., Jones, B. E. \& van Steenbergen, R. (1996). Phylogenetic diversity of soda lake alkaliphiles. FEMS Microbiol Ecol 19, 181-191.

Gomori, G. (1955). Preparation of buffers for use in enzyme studies. Methods Enzymol 1, 138-146.

Grant, W. D., Kamekura, M., McGenity, T. J. \& Ventosa, A. (2001). Order I. Halobacteriales Grant and Larsen 1989b, 495 ${ }^{\mathrm{VP}}$ (Effective publication: Grant and Larsen 1989a, 2216). In Bergey's Manual of Systematic Bacteriology, 2nd edn, vol. 1, pp. 294-334. Edited by D. R. Boone, R. W. Castenholz \& G. M. Garrity. New York: Springer.

Gutiérrez, M. C., Castillo, A. M., Kamekura, M., Xue, Y., Ma, Y., Cowan, D. A., Jones, B. E., Grant, W. D. \& Ventosa, A. (2007). Halopiger xanaduensis gen. nov., sp. nov., an extremely halophilic archaeon isolated from saline Lake Shangmatala in Inner Mongolia, China. Int J Syst Evol Microbiol 57, 1402-1407.

Hezayen, F. F., Rehm, B. H. A., Tindall, B. J. \& Steinbüchel, A. (2001). Transfer of Natrialba asiatica B1T to Natrialba taiwanensis sp. nov. and description of Natrialba aegyptiaca sp. nov., a novel extremely halophilic, aerobic, non-pigmented member of the Archaea from Egypt that produces extracellular poly(glutamic acid). Int J Syst Evol Microbiol 51, 1133-1142.

Johnson, J. L. (1994). Similarity analysis of DNAs. In Methods for General and Molecular Bacteriology, pp. 655-681. Edited by P. Gerhardt, R. G. E. Murray, W. A. Wood \& N. R. Krieg. Washington, DC: American Society for Microbiology.

Kamekura, M. (1993). Lipids of extreme halophiles. In The Biology of Halophilic Bacteria, pp. 135-161. Edited by R. H. Vreeland \& L. I. Hochstein. Boca Raton, FL: CRC Press.

Kamekura, M. \& Dyall-Smith, M. L. (1995). Taxonomy of the family Halobacteriaceae and the description of two new genera Halorubrobacterium and Natrialba. J Gen Appl Microbiol 41, 333-350.

López-García, P., Moreira, D., López-López, A. \& Rodríguez-Valera, F. (2001). A novel haloarchaeal-related lineage is widely distributed in deep oceanic regions. Environ Microbiol 3, 72-78.

Ludwig, W., Strunk, O., Klugbauer, S., Klugbauer, N., Weizenernegger, M., Neumaier, J., Bachleitner, M. \& Schleifer, K.-H. (1998). Bacterial phylogeny based on comparative sequence analysis. Electrophoresis 19, 554-568.

Ludwig, W., Strunk, O., Westram, R., Richter, L., Meier, H., Yadhukumar, Buchner, A., Lai, T., Steppi, S. \& other authors (2004). ARB: a software environment for sequence data. Nucleic Acids Res 32, 1363-1371.

Marmur, J. (1961). A procedure for the isolation of deoxyribonucleic acid from microorganisms. J Mol Biol 3, 208-218.

Marmur, J. \& Doty, P. (1962). Determination of the base composition of deoxyribonucleic acid from its thermal denaturation temperature. J Mol Biol 5, 109-118.

Oren, A., Ventosa, A. \& Grant, W. D. (1997). Proposed minimal standards for description of new taxa in the order Halobacteriales. Int J Syst Bacteriol 47, 233-238.

Oren, A., Arahal, D. R. \& Ventosa, A. (2009). Emended descriptions of genera of the family Halobacteriaceae. Int J Syst Evol Microbiol 59, 637-642.

Owen, R. J. \& Hill, L. R. (1979). The estimation of base compositions, base pairing and genome sizes of bacterial deoxyribonucleic acids. In 
Identification Methods for Microbiologists (Society for Applied Bacteriology Technical Series no. 14), 2nd edn, pp. 277-296. Edited by F. A. Skinner \& D. W. Lovelock. London: Academic Press.

Saitou, N. \& Nei, M. (1987). The neighbor-joining method: a new method for reconstructing phylogenetic trees. Mol Biol Evol 4, 406425.

Savage, K. N., Krumholz, L. R., Oren, A. \& Elshahed, M. S. (2007). Haladaptatus paucihalophilus gen. nov., sp. nov., a halophilic archaeon isolated from a low-salt, sulfide-rich spring. Int J Syst Evol Microbiol 57, 19-24.

Savage, K. N., Krumholz, L. R., Oren, A. \& Elshahed, M. S. (2008). Halosarcina pallida gen. nov., sp. nov., a halophilic archaeon from a low-salt, sulfide-rich spring. Int J Syst Evol Microbiol 58, 856-860.

Stackebrandt, E., Fredericksen, W., Garrity, G. M., Grimont, P. A. D., Kämpfer, P., Maiden, M. C. J., Nesme, X., Rosselló-Mora, R., Swings, J. \& other authors (2002). Report of the ad hoc committee for the re-evaluation of the species definition in bacteriology. Int J Syst Evol Microbiol 52, 1043-1047.

Torreblanca, M., Rodriguez-Valera, F., Juez, G., Ventosa, A., Kamekura, M. \& Kates, M. (1986). Classification of non-alkaliphilic halobacteria based on numerical taxonomy and polar lipid composition, and description of Haloarcula gen. nov. and Haloferax gen. nov. Syst Appl Microbiol 8, 89-99.

Ventosa, A. (2006). Unusual microorganisms from unusual habitats: hypersaline environments. In Prokaryotic Diversity: Mechanisms and Significance (Society for General Microbiology Symposium no. 66), pp. 223-253. Edited by N. A. Logan, H. M. Lappin-Scott \& P. C. F. Oyston. Cambridge: Cambridge University Press.

Xu, Y., Zhou, P. \& Tian, X. (1999). Characterization of two novel haloalkaliphilic archaea, Natronorubrum bangense gen. nov., sp. nov. and Natronorubrum tibetense gen. nov., sp. nov. Int J Syst Bacteriol 49, 261-266. 